\title{
THE AFRICAN TRANSFORMATIVE NOTION OF UBUNTU AND THE ENDURANCE OF THE ROMAN QUASI-CONTRACT OF NEGOTIORUM GESTIO WITHIN THE SOUTH AFRICAN CONSTITUTIONAL DISPENSATION
}

\author{
by Mpho Mogadime*
}

\section{Introduction}

Certain Roman law principles and rules in the South African legal system have been subject to scrutiny, especially amidst the constitutional mandate to develop the South African common law in conformity with the underlying values of the Constitution. ${ }^{1}$ This scrutiny fundamentally stems from the historical imposition of Roman-Dutch law on (South) African customary law during the seventeenth century, the lack of its true reception thereof, and subsequently, the question of its relevance, (dis)use and legitimacy in a post-apartheid constitutional dispensation. ${ }^{2}$

This article serves as a focused discourse on the endurance of the Roman quasi-contract of negotiorum gestio in South African law, so as to establish whether or not this particular rule has been abrogated by disuse and whether, in view of the African transformative notion of ubuntu, it is upheld by the Constitution. I will firstly provide a brief definition and practical operation of the quasi-contract. Secondly, I will discuss whether negotiorum gestio has been abrogated by disuse, with a brief analysis of the doctrine of abrogation. And lastly, I will discuss the constitutional validity of negotiorum gestio, in light of the African transformative notion of ubuntu, including antithetical views on the validity of the quasi-contract.

* Second year BCom Law student, University of Pretoria.

1 Sec 39(2) of the Constitution of the Republic of South Africa, 1996 (the Constitution).

2 G van Niekerk 'The endurance of the Roman tradition in South African law' http:/ /studia.law.ubbcluj.ro/articol/474 (accessed 20 June 2016). 


\section{The quasi-contract of negotiorum gestio and its operation in South African law}

The quasi-contract of negotiorum gestio is briefly defined as the voluntary and unauthorised management of the affairs of another person. ${ }^{3}$ The description of negotiorum gestio as a quasi-contract is derived from the basis that, unlike the establishment of the Roman law contract, which required consensus and a causa contractus, ${ }^{4}$ negotiorum gestio does not require consensus in order for reciprocal rights and duties to exist between parties to the contract. ${ }^{5}$ However, certain requirements have to be met for a negotiorum gestio to be established. There must exist an intention by the manager (the gestor) to manage the affairs of another person (the dominus), so as to further the interests of that person. Such an example of this can be found in Absa Bank Ltd t/a BANKFIN $v$ Stander t/a Caw Paneelkloppers. ${ }^{6}$ Such management must be unauthorised, but useful to the dominus. ${ }^{7}$ The gestor should be able to justify this unauthorised interference or meddling, and rights and duties can only arise after the affairs of the dominus have indeed been managed. ${ }^{8}$

The consequences of the fulfillment of the abovementioned requirements are that the gestor may only claim compensation for the expenses incurred while managing the affairs of the dominus, but neither remuneration nor reward can be claimed, ${ }^{9}$ in that such factors are extrinsic to the quasi-contract. The compensation is claimed through the actio negotiorum gestorum, which is a legal remedy available for a gestor who wishes to claim compensation from the dominus for delivering performance.

The practical operation of negotiorum gestio would be applicable in instances such as if, for example, $M$ and $D$ are divorced, and $K$ is the biological child of $M$ (the mother) and $D$ (the father). $D$ had been paying maintenance for $\mathrm{K}$ throughout the duration of her years as a minor. As $\mathrm{K}$ began her studies at a tertiary institution, $\mathrm{D}$ disappears and is nowhere to be found. $\mathrm{K}$ is in the possession of a study bursary that covers all expenses, excluding basic food items and accommodation. Consequently, M, along with C (K's uncle-in-law), solely contribute to the expenses not covered by the bursary. After a

$3 \mathrm{DH}$ van Zyl Negotiorum gestio in South African law: an historical and comparative analysis (1985) 3-4.

4 PhJ Thomas et al Historical foundations of South African private law (2000) 224. This refers to the reason for the contract.

5 Van Zyl (n 3 above) 4.

61998 (1) SA 939 (C) 940 . This intention is known as the animus negotia aliena gerendi.

$7 \quad$ Van Zyl (n 3 above) 8.

8 Van Zyl (n 3 above) 11.

9 Van Zyl (n 3 above) 14. 
few years, $C$ learns of the whereabouts of $D$. C then decides to institute an action against $D$, to claim compensation for the maintenance fees paid for $\mathrm{K}$, on the grounds that he had acted as a gestor by managing D's affairs, which included D's obligation to maintain $\mathrm{K}$, even though $\mathrm{K}$ had passed the age of majority. This was confirmed in Bursey $\vee$ Bursey. ${ }^{10}$

In instances such as the above circumstances, negotiorum gestio would be applicable in favour of $C$, in that all the requirements mentioned above for the existence of the quasi-contract are fulfilled and $\mathrm{C}$ would be able to claim compensation for his voluntary, unauthorised management of the affairs of $D$.

\section{Has negotiorum gestio been abrogated by disuse?}

The doctrine of abrogation is founded on the rule that law may be tacitly repealed (or abrogated) by the prolonged lack of its use, which is mainly determined by the silent consent of an entire community. This was confirmed in the case of $\mathrm{S} v$ Hoho. ${ }^{11}$ Factors used to measure this silent consent are, among other things, the number of prosecutions or convictions involving the particular law, ${ }^{12}$ any recent developments or extensions of that law, ${ }^{13}$ and existing academic articles and/or books concerning that particular law. ${ }^{14}$ In this regard, it is necessary to analyse whether or not negotiorum gestio has been abrogated by disuse.

In the case of Sheriff of Cape Town v Mt Argun (MT Argun case), ${ }^{15}$ which dealt with maritime law, the court recognised negotiorum gestio as a valid basis on which a party can claim contractual performance. The appeal case concerned the legal obligation of a Sheriff to keep custody of an arrested ship. ${ }^{16}$ Neither the arresting parties nor the owner of the ship contributed to the preservation costs of the ship held under the Sheriff, who was then acting in the interests and for the benefit of the arresting parties in respect to the payment of the preservation costs (which was not a statutory mandate). Recognising the apparent quasi-contract, Scott JA held that: ${ }^{17}$ maintain extends beyond the age of majority.

1120091 SACR 276 (SCA) para 9.

12 Hoho (n 11 above) para 11.

13 Hoho (n 11 above) para 12-13.

14 Hoho (n 11 above) para 14.

152001 (3) SA 1230 (SCA).

16 Rule 21(1) of the Admiralty Proceedings Rules.

17 MT Argun (n 15 above) para 31. 
It was further argued that in preserving the vessel the Sheriff was acting as a negotiorum gestor ... the Sheriff was in fact managing the affairs of the arresting parties by preserving their security.

Furthermore, the quasi contract is discussed, considered, and even extended in various academic articles, ${ }^{18}$ books, ${ }^{19}$ and cases. This ranges from cases dealing with unjustified enrichment, ${ }^{20}$ improvements, ${ }^{21}$ and even maintenance. ${ }^{22}$ The apparent reluctance to completely repeal the negotiorum gestio, but rather to extend its action for recovery when dealing with specific facts, while continuing to refer to the prerequisites of the quasi-contract in order to establish whether or not it can be applied in its ordinary sense in such facts, proves that there is a strong preservation of the quasi-contract.

It can, therefore, be deduced that the Roman quasi-contract of negotiorum gestio has not been abrogated by disuse, as there exists little evidence of silence from the entire community and the quasicontract is still applicable in cases where all the requirements needed for the quasi-contract to exist are complied with, so as to further the interests of justice. ${ }^{23}$

\section{The constitutional validity of negotiorum gestio and ubuntu}

In the post-apartheid legal context, the question of constitutional validity in South African law is always pertinent; in light of constitutional supremacy. ${ }^{24}$ Langa mentions that one of the goals of 'transformative constitutionalism' is achieving a culture of justification, ${ }^{25}$ which entails justifying court decisions 'by reference to ideas and values'.26

Some of the underlying values that informed the establishment of negotiorum gestio are values such as good faith, ${ }^{27}$ reliability,

18 LJW Aitken 'Negotiorum gestio and the common law' (1988) 11 Sydney Law Review 566; A K Blommaert 'Negotiorum gestio and the life-rescuer' (1981) 2 Journal of South African Law 123.

19 Van Zyl (n 3 above); J du Plessis The South African law of unjustified enrichment (2012); R Zimmermann et al Mixed legal systems in comparative perspective: Property and obligations in Scotland and South Africa (2004); R Zimmermann The law of obligations: Roman foundations of the civilian tradition (1990).

20 Absa Bank (n 6 above); B \& H Engineering v First National Bank Of SA Ltd 1995 (2) SA 279 (A).

21 Gouws v Jester Pools (Pty) Ltd 1968 (3) SA 563 (T).

22 Governing Body, Gene Louw Primary School v Roodtman 2004 (1) SA 45 (C).

23 Zimmermann et al (n 19 above) 373.

24 Sec 2 of the Constitution.

25 P Langa 'Transformative constitutionalism' (2006) 3 Stellenbosch Law Review 351. The object of transformative constitutionalism is to transform society through the lens of the Constitution.

26 Langa (n 25 above) 353.

27 Van Zyl (n 3 above) 23. 
friendship, respect, kindness, and courteous service; which functioned to create a type of value system in society. ${ }^{28}$ These values are synonymous with those key values of the African indigenous concept of ubuntu, ${ }^{29}$ namely, 'group solidarity, conformity, compassion, respect, human dignity, humanistic orientation and collective unity'.30

The interim constitution, from which the current supreme Constitution is derived, states that one of the important objectives of a post-apartheid legal order is the implementation of solutions that address the need for ubuntu. ${ }^{31}$ This reveals the strong correlation between the current supreme Constitution and the values underlying the concept of ubuntu. In her article titled, 'Ubuntu and the Law in South Africa', ${ }^{32}$ Mokgoro argues that the aforementioned values of ubuntu are in conformity with the underlying values of the Constitution, especially those in the Bill of Rights, such as human dignity, freedom, and equality. It is also clear in its preamble that the Constitution aims to create a unified society, ${ }^{33}$ which is an objective that supports one of the underlying philosophies of ubuntu, that 'motho ke motho ka batho ba bangwe / umuntu ngumuntu ngabantu', which means that an individual is only a truly fulfilled person through the help of others (that is, a sense of communality). Moreover, the notion of ubuntu is regarded as a backdrop to African customary law, ${ }^{34}$ the latter of which is explicitly upheld by the Constitution. ${ }^{35}$ The particular quasi-contract in African customary family law is known as isondlo, whereby compensation may be claimed for the maintenance of a child or adult (in rare circumstances) who is not a member of the immediate family group. ${ }^{36}$

In view of the agreement between the underlying values that inform the Roman quasi-contract of negotiorum gestio and the values of ubuntu, it is submitted that negotiorum gestio is also in conformity with the Constitution, and therefore supported by it. The quasicontract can also be seen to give effect to the 'spirit, purport and objects of the Bill of Rights', 37 through the underlying values that inform it.

30 JY Mokgoro 'Ubuntu and the law in South Africa' (1998) 1 Potchefstroom Electronic Law Journal 17.

31 Provision on 'National unity and reconciliation' in the postscript of the Interim Constitution of the Republic of South Africa, 1993.

32 Mokgoro (n 30 above) 24.

33 Preamble of the Constitution; 'Build a united and democratic South Africa able to take its rightful place as a sovereign state in the family of nations'.

34 D Kleyn \& G van Niekerk 'Ulpian's Praecepta luris and their role in South African law part 2: Modern-day South African practice' (2014) 20 Fundamina (Pretoria) $446-447$.

35 Secs 39(3) \& 211(3) of the Constitution.

36 C Rautenbach \& JC Bekker Introduction to legal pluralism (2014) 153.

37 Sec $39(2)$ of the Constitution. 


\section{$5 \quad$ Antithetical views on the validity of negotiorum gestio}

However, there exist antithetical views against the argument established above. One of the dissenting arguments is that firstly, the benefit given by the gestor is inseparably entangled with the entitlements of the dominus to whatever thing or performance that is involved and this had been done without the consent of the dominus. That being argued, the dominus can only be liable for non-donative performance. ${ }^{38}$ Secondly, English case law, which the Constitution recognises as a persuasive force, ${ }^{39}$ states that such an action as negotiorum gestio will compel ill-willed individuals to take a mala fide advantage of others. ${ }^{40}$

With regards to the first argument, which absolves the dominus from liability, Van Zijl JP rather held to the contrary that '... meddling [in the affairs of another] is allowed in circumstances where such meddling is necessary in order to do justice between man and man. ${ }^{\prime 4}$

This is in agreement with the latter position in the MT Argun case, and it further reveals that the object of recognising rights and duties arising from unauthorised management is not whether the dominus has given consent or not, but rather to administer justice where nongratuitous 'meddling' is done to the benefit of the dominus. And even where there arose circumstances whereby negotiorum gestio could not be applied in its ordinary sense, the gestor could, mutatis mutandis, still claim through the extended actio negotiorum gestorum, which would limit the gestor to recover the amount by which the dominus was unjustifiably enriched at the expense of the gestor. $^{42}$

In response to the second argument based on English case law, it is submitted that the firm position of the Constitution with regards to common law (that is, Roman-Dutch law as influenced by English law), is as follows: ${ }^{43}$

The Bill of Rights does not deny the existence of any other rights or freedoms that are recognized or conferred by common law, customary law or legislation, to the extent that they are consistent with the Bill.

This section of the constitution corresponds with a well-founded principle in South African law, and that is the principle of avoidance. This principle was firmly established by the Constitutional Court in the

38 N Fakude 'Redundant or relevant?' (2015) 551 De Rebus 36.

39 Sec 39(1)(c) of the Constitution.

40 Fakude (n 38 above).

41 Standard Bank Financial Services Ltd v Taylam (Pty) Ltd 1979 (2) SA 383 (C) 392.

42 Absa Bank (n 6 above) 944-945.

$43 \mathrm{Sec} 39(3)$ of the Constitution. 
case of $S \vee$ Mhlungu, ${ }^{44}$ where the court held that where it is possible to resolve any dispute without reaching a constitutional issue, that is the course that should be followed. It follows from this that since negotorium gestio forms part of common law, which is protected by section 39(3) of the Constitution, it is given effect to and considered as valid law ab initio, until such a time where, in light of constitutional scrutiny, it is struck down by a court of law.

On the contrary, the courts have so far upheld quasi-contracts. ${ }^{45}$ In the case of My vote counts NPC v Speaker of the National Assembly and Others (My vote counts case), the Constitutional Court held that: ${ }^{46}$

Far from avoiding constitutional issues whenever possible, the court has emphasised that virtually all issues - including the interpretation and application of legislation and the development and application of the common law are, ultimately, constitutional. This is because the Constitution's rights and values give shape and colour to all law.

The exception to the abovementioned precedence would of course be where common law is inconsistent with provisions of the constitution. In such an instance, the court would be obliged to develop such common law to bring it in conformity with the constitution. ${ }^{47}$ It can clearly be inferred from My vote counts that the Constitution does in fact uphold the quasi-contract of negotiorum gestio as part of common law, as it is quite apparent from the discussions above that the quasi-contact in itself is in conformity with the Constitution through the values that inform it.

\section{Conclusion}

Within the current era of constitutionalism, a focus is placed on a substantive approach to the law, which is based on the underlying values of the Constitution. Moseneke reiterates this in his article titled, 'Transformative adjudication', 48 that part of advancing the constitutional goal of transformation is the pursuit of 'substantive justice' through applying the 'foundational values of the Constitution'. ${ }^{49}$ These values are evident in the underlying values of the Roman quasi-contract of negotiorum gestio and are in agreement with the underlying values that inform the African transformative

1995 (3) SA 867 (CC) para 59.

As discussed in case law above.

2016 (1) SA 132 (CC) paras 51-52.

47 Carmichele $v$ Minister of Safety and Security 2001 (4) SA 938 (CC) para 40. Further see secs 39(2)-(3) of the Constitution.

48 D Moseneke 'Transformative adjudication' (2002) 18 South African Journal on Human Rights 309.

49 Moseneke (n 48 above) 316. 
notion of ubuntu, which can be said to be at first glance in conformity with the Constitution.

It can, therefore, be concluded that negotiorum gestio has not been abrogated by disuse; and moreover, it is supported by the Constitution. The quasi-contract is also a contribution, through the values that inform it, to the greater goal of transformation in South African jurisprudence. 